Communication

\title{
Microwave Assisted Synthesis of 4-Phenylquinazolin-2(1H)-one Derivatives that Inhibit Vasopressor Tonus in Rat Thoracic Aorta
}

\author{
Rafaela Teixeira $^{1, *(0)}$, Talita Menengat ${ }^{2}$, Gabriel Andrade ${ }^{3}$, Bruno Cotrim ${ }^{3}$, Cristiano Ponte ${ }^{2}$, \\ Wilson C. Santos ${ }^{1} \mathbb{D}$ and Gabriel Resende ${ }^{3}$ \\ 1 Programa de Pós-Graduação em Ciências Aplicadas a Produtos para a Saúde, Faculdade de Farmácia, \\ Universidade Federal Fluminense, Niterói 24241-000, RJ, Brazil; wsantos@id.uff.br \\ 2 Núcleo de Ciência Biomédicas Aplicadas, Instituto Federal do Rio de Janeiro, Rio de Janeiro 20270-021, RJ, \\ Brazil; talymenengat@yahoo.com.br (T.M.); cristiano.ponte@ifrj.edu.br (C.P.) \\ 3 Núcleo de Ciências Químicas, Instituto Federal do Rio de Janeiro, Rio de Janeiro 20270-021, RJ, Brazil; \\ gfa.ifrj@gmail.com (G.A.); bruno.cotrim@ifrj.edu.br (B.C.); gabriel.resende@ifrj.edu.br (G.R.) \\ * Correspondence: rafaelagomes@id.uff.br; Tel.: +55-(21)-983974444
}

Received: 12 February 2020; Accepted: 14 March 2020; Published: 24 March 2020

check for updates

\begin{abstract}
Quinazolinones have pharmacological effects on vascular reactivity through different mechanisms. We synthesized 4-phenylquinazolin-2 $(1 \mathrm{H})$-one derivatives under microwave irradiation and tested them on the rat thoracic aorta. The prepared compounds $\mathbf{2 a}-\mathbf{2} \mathbf{f}$ were obtained in about $1 \mathrm{~h}$ with suitable yields (31-92\%). All derivatives produced vasorelaxant effects with $\mathrm{IC}_{50}$ values ranging from $3.41 \pm 0.65 \mu \mathrm{M}$ to $39.72 \pm 6.77 \mu \mathrm{M}$. Compounds $2 \mathrm{c}, 2 \mathrm{e}$ and $2 \mathrm{f}$ demonstrated the highest potency in endothelium-intact aorta rings ( $\mathrm{IC}_{50} 4.31 \pm 0.90 \mu \mathrm{M}, 4.94 \pm 1.21 \mu \mathrm{M}$ and $3.41 \pm 0.65 \mu \mathrm{M}$ respectively), and they achieved around $90 \%$ relaxation $(30 \mu \mathrm{M})$. In aorta rings without an endothelium, the effect of compound $2 \mathrm{f}$ was abolished. Using the MTT assay to test for cell viability, only compound $2 \mathrm{~b}$ induced cytotoxicity at the maximum concentration employed $(30 \mu \mathrm{M})$. The results show that vasorelaxation by 4-phenylquinazolin-2(1H)-one derivatives might depend on the activation of a signalling pathway triggered by endothelium-derived factors.
\end{abstract}

Keywords: microwave irradiation; 4-phenylquinazolin-2(1H)-one; vasorelaxation; endothelium; rat thoracic aorta

\section{Introduction}

Heterocyclic drugs make up over $60 \%$ of major retail medicines for the pharmaceutical market $[1,2]$. Considering the heterocyclic quinazolines and quinazolinone-containing compounds, they have already shown pharmacological relevance with broad therapeutic potential [3]. Hence, several quinazoline and quinazolinones have been applied in the chemical and pharmaceutical fields, and many of them have already been approved as medicines [4]. Quinazolinones are heterocyclic chemical compounds with two structural isomers, namely quinazolin-2(1H)-one and quinazolin- $4(3 \mathrm{H})$-one (Figure 1$)$; the latter is the most investigated in the literature [5]. 
<smiles>c1ccc2ncncc2c1</smiles>

Quinazoline<smiles>O=c1ncc2ccccc2[nH]1</smiles>

Quinazolin-2(1H)-one<smiles>O=c1[nH]cnc2ccccc12</smiles>

Quinazolin-4(3H)-one

Figure 1. Quinazoline and quinazolinone structures.

Quinazoline derivatives have also demonstrated antihypertensive effects, such as the class of the alpha 1-adrenergic $(\alpha 1)$ receptor antagonists used in the treatment of hypertension [6,7]. Drugs such as prazosin or terazosin act on vascular smooth muscle receptors, leading to vasodilation and a consequent reduction in peripheral vascular resistance; these medications are used for the treatment of benign prostatic hyperplasia (BPH) [8]. Concerning their antihypertensive effects, quinazolines have shown activity on vascular reactivity through different mechanisms such as the modulation of T-type calcium channels [9], angiotensin converting enzyme (ACE) [10] and phosphodiesterase-5 (PDE-5) [11]. Indeed, several therapeutic activities of quinazolines and their derivatives have been reported in the literature, including antimicrobial [12], antitumor [13,14] and anticonvulsant [15]. In addition, interest in the synthesis and biological activity of quinazolinones and quinazolines has contributed to the growing number of new patents for such molecules in recent years [4].

Thereby, considering all this knowledge, the existence of several reports on vascular activity attributed to quinazolines and, notably, few studies that focus on the biological effects of the isomer quinazolin-2 $(1 \mathrm{H})$-one, we decided to investigate the putative effects of its derivatives on the rat thoracic aorta. In the present investigation, we synthesized 4-phenylquinazolin-2(1H)-one derivatives synthetized under microwave irradiation and tested them for their vasorelaxation properties using experimental protocols on the rat thoracic aorta.

\section{Results and Discussion}

\subsection{Chemistry}

Several methodologies for the 4-phenylquinazolin-2(1H)-one scaffold have been described in the literature; however, they require prolonged reaction times [16,17] or expensive reagents [18-21]. Most of the time heating using microwave radiation allows one to drastically reduce times and increase the yield of reactions. Microwave radiation provides more efficient heating since it is generated internally by direct absorption of microwave radiation by polar molecules present in the reaction mixture (for example solvents, reagents and catalysts) [22,23]. In order to improve the existing synthesis protocol, a series of 4-phenylquinazolin-2(1H)-one derivatives were synthetized using a conventional methodology and microwave (MW) irradiation with urea and substituted 2-aminobenzophenones as the preliminary compounds (Scheme 1). The results are recorded in Table 1.

Table 1 shows that the methodology using microwave heating provided higher yields and required less reaction time compared with the traditional methodology. The compounds $\mathbf{2 a}-\mathbf{f}$, except compound $\mathbf{2 b}$, were obtained in less than $1 \mathrm{~h}$ and obtained with good yields (63-92\%). Compound $\mathbf{2 b}$, which has an electron withdrawing group (nitro group), had very poor yield with the traditional methodology $(16 \%)$, but this was increased using the microwave methodology $(31 \%)$. 
<smiles>[R7]Nc1ccc([R7])cc1C(=O)c1ccccc1[R7]</smiles>

$$
\begin{aligned}
& \text { or } \mathrm{MW} \\
& \text { a: } \mathrm{R}_{1}=\mathrm{H} ; \mathrm{R}_{2}=\mathrm{H} ; \mathrm{R}_{3}=\mathrm{H} \\
& \text { b: } \mathrm{R}_{1}=\mathrm{NO}_{2} ; \mathrm{R}_{2}=\mathrm{H} ; \mathrm{R}_{3}=\mathrm{H} \\
& \text { c: } \mathrm{R}_{1}=\mathrm{Cl} ; \mathrm{R}_{2}=\mathrm{Me} ; \mathrm{R}_{3}=\mathrm{H} \\
& \text { d: } \mathrm{R}_{1}=\mathrm{Cl} ; \mathrm{R}_{2}=\mathrm{F} ; \mathrm{R}_{3}=\mathrm{H} \\
& \text { e: } \mathrm{R}_{1}=\mathrm{Br} ; \mathrm{R}_{2}=\mathrm{H} ; \mathrm{R}_{3}=\mathrm{H} \\
& \text { f: } \mathrm{R}_{1}=\mathrm{Cl} ; \mathrm{R}_{2}=\mathrm{H} ; \mathrm{R}_{3}=\mathrm{Me}
\end{aligned}
$$<smiles>[R7]c1ccc2c(c1)c(-c1ccccc1[R7])nc(=O)n2[P]</smiles>

Scheme 1. Synthesis of 4-phenylquinazolin-2(1H)-one derivatives.

Table 1. Optimization of reaction conditions for the synthesis of compounds 2a-f.

\begin{tabular}{cccc}
\hline Compound & Method & Yield (\%) & Time \\
\hline $\mathbf{2 a}$ & Conventional & 78 & $18 \mathrm{~h}$ \\
\hline $\mathbf{2 a}$ & MW & 92 & $30 \mathrm{~min}$ \\
\hline $\mathbf{2 b}$ & Conventional & 16 & $30 \mathrm{~h}$ \\
\hline $\mathbf{2 b}$ & MW & 31 & $45 \mathrm{~min}$ \\
\hline $\mathbf{2 c}$ & Conventional & 67 & $24 \mathrm{~h}$ \\
\hline $\mathbf{2 c}$ & MW & 89 & $30 \mathrm{~min}$ \\
\hline $\mathbf{2 d}$ & Conventional & 78 & $22 \mathrm{~h}$ \\
\hline $\mathbf{2 d}$ & MW & 80 & $30 \mathrm{~min}$ \\
\hline $\mathbf{2 e}$ & Conventional & 68 & $24 \mathrm{~h}$ \\
\hline $\mathbf{2 e}$ & MW & 63 & $30 \mathrm{~min}$ \\
\hline $\mathbf{2 f}$ & Conventional & 85 & $28 \mathrm{~h}$ \\
\hline $\mathbf{2 f}$ & MW & 88 & $30 \mathrm{~min}$ \\
\hline
\end{tabular}

\subsection{Biological Evaluation}

All tested compounds induced concentration-dependent relaxation $\left(\mathrm{IC}_{50}\right.$ ranging from $3.41 \pm 0.65 \mu \mathrm{M}$ to $39.72 \pm 6.77 \mu \mathrm{M})$ in endothelium-intact aorta arterial rings pre-contracted with Phe $1 \mu \mathrm{M}$ (Table 2, Figures 2 and 3). The cumulative addition of increasing concentrations of the studied compounds potentiated the observed vasorelaxant effect. Compound $\mathbf{2} \mathbf{f}$ was found to be the most potent in endothelium-intact vessels $\left(\mathrm{IC}_{50}=3.41 \pm 0.65 \mu \mathrm{M}\right)$, while compounds $\mathbf{2 a}, \mathbf{2} \mathbf{b}$ and $\mathbf{2 d}$ showed the lowest potency in the endothelium-intact aorta at the concentrations employed in the present study. Additionally, compounds $\mathbf{2 c}, \mathbf{2 e}$ and $\mathbf{2 f}$ demonstrated the highest potency with an $\mathrm{IC}_{50}$ of $4.31 \pm 0.90 \mu \mathrm{M}, 4.94 \pm 1.21 \mu \mathrm{M}$ and $3.41 \pm 0.65 \mu \mathrm{M}$, respectively, and they achieved around $90 \%$ relaxation at the highest concentration of $30 \mu \mathrm{M}$ in endothelium-intact aorta rings. Thus, we decided to test compound $2 \mathbf{f}$ at lower concentrations (30-300 $\mathrm{nM}$ ) in endothelium-intact and endothelium-denuded aorta rings. 
Table 2. Compounds identification (ID), molecular weight and $\mathrm{IC}_{50}$ vasorelaxation response in endothelium-intact (E+) aorta arterial vessels.

\begin{tabular}{cccccc}
\hline Compound ID & $\mathbf{R}_{\mathbf{1}}$ & $\mathbf{R}_{\mathbf{2}}$ & $\mathbf{R}_{\mathbf{3}}$ & $\mathbf{M W}(\mathbf{g} / \mathbf{m o l})$ & IC $_{\mathbf{5 0}}(\boldsymbol{\mu M})$ \\
\hline $\mathbf{2 a}$ & $\mathrm{H}$ & $\mathrm{H}$ & $\mathrm{H}$ & 222.24 & $39.72 \pm 6.77$ \\
\hline $\mathbf{2 b}$ & $\mathrm{NO}_{2}$ & $\mathrm{H}$ & $\mathrm{H}$ & 267.24 & $16.39 \pm 3.50$ \\
\hline $\mathbf{2} \mathbf{C l}$ & $\mathrm{Me}$ & $\mathrm{H}$ & 270.71 & $4.31 \pm 0.90$ \\
\hline $\mathbf{2 d}$ & $\mathrm{Cl}$ & $\mathrm{F}$ & $\mathrm{H}$ & 274.68 & $26.53 \pm 8.98$ \\
\hline $\mathbf{2 e}$ & $\mathrm{Br}$ & $\mathrm{H}$ & $\mathrm{H}$ & 301.13 & $4.94 \pm 1.21$ \\
\hline $\mathbf{2 f}$ & $\mathrm{Cl}$ & $\mathrm{H}$ & $\mathrm{Me}$ & 270.71 & $3.41 \pm 0.65$ \\
\hline
\end{tabular}<smiles>[R7]c1ccc2c(c1)c(-c1ccccc1[R7])nc(=O)n2[Z]</smiles>

Figure 2. Structure of 4-phenylquinazolin-2(1H)-one derivatives.
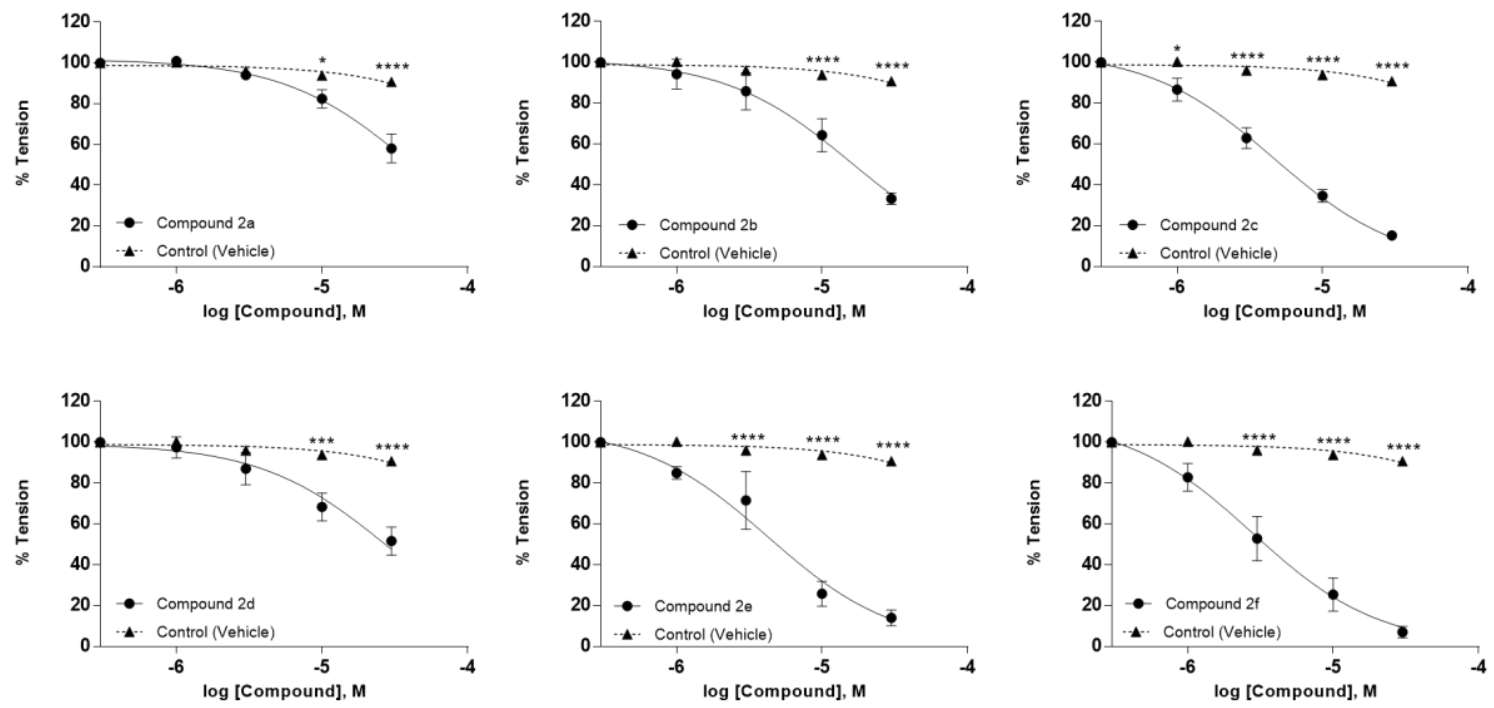

Figure 3. Concentration-response curves for compounds $\mathbf{2 a}-\mathbf{f}$ and control (vehicle: DMSO) in intact endothelium aortic rings pre-contracted with Phe $1 \mu \mathrm{M}$. Cumulative concentrations $(1 \mu \mathrm{M}, 3 \mu \mathrm{M}, 10 \mu \mathrm{M}$ and $30 \mu \mathrm{M}$ ) were added to the Phe contraction plateau. DMSO was employed at the same volume used to dissolve the compound stock solution (maximum final concentration at $0.3 \%$ ). All data are expressed as mean \pm standard error of the mean (SEM) $(n=4-5) .\left({ }^{*} P<0.05 ;{ }^{* * *} P<0.001\right.$; ${ }^{* * * *} P<0.0001$ compound vs. control).

Preliminarily, we decided to investigate the effect of compound $\mathbf{2 f}$, as the most effective in the series, in an experimental model without the endothelium to assess its possible involvement on the observed vasorelaxation. A representative record of cumulative concentrations of compound $2 \mathrm{f}(1 \mu \mathrm{M}$, $3 \mu \mathrm{M}, 10 \mu \mathrm{M}$ and $30 \mu \mathrm{M}$ ) on aortic rings endothelium-intact and endothelium-denuded pre-contracted with Phe $1 \mu \mathrm{M}$ are shown in Figure 4. Phe induced a steady tone in both preparations that were greater 
in endothelium denuded rings. The results demonstrate that vasorelaxation was abolished in the absence of the endothelium.

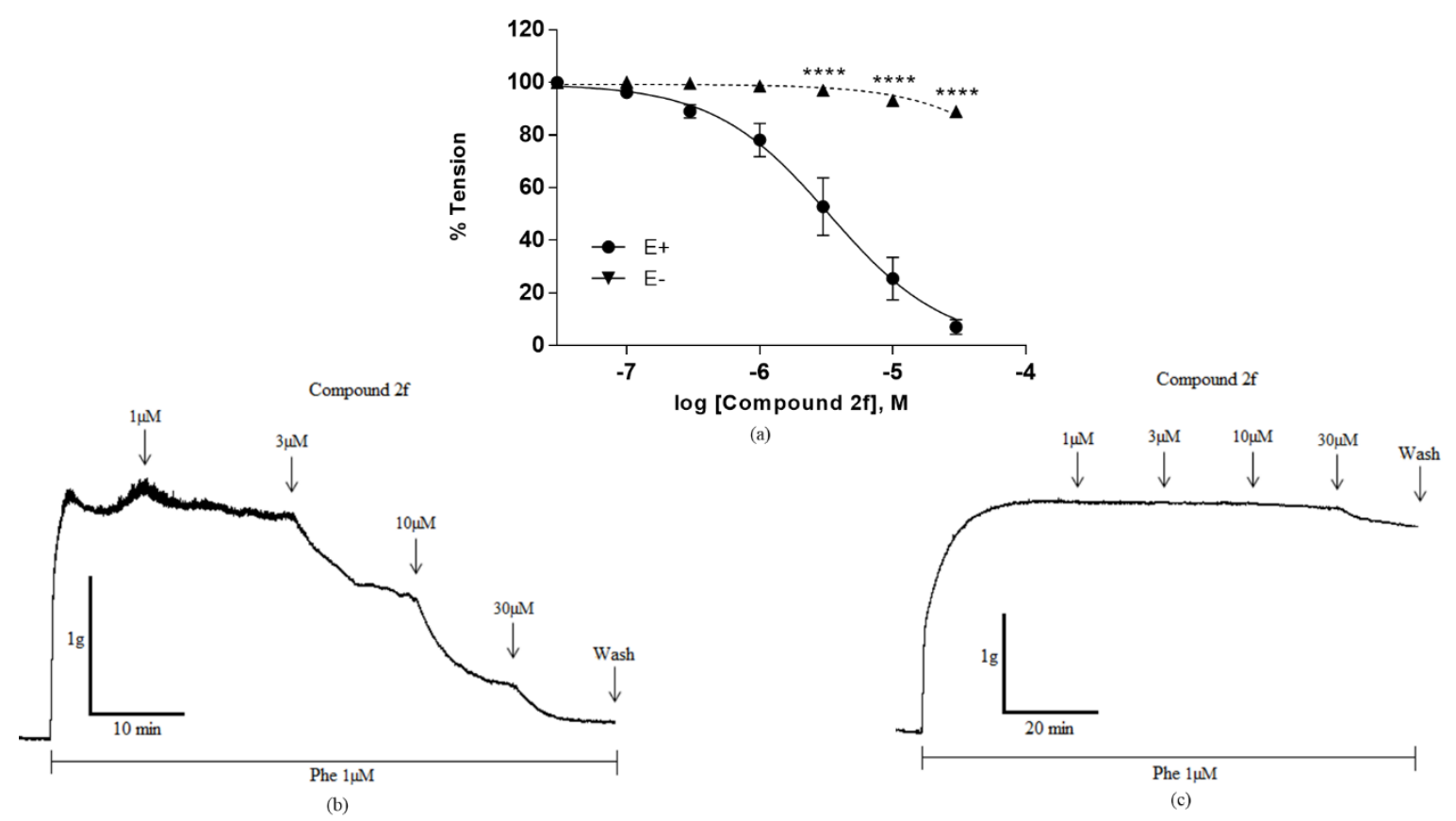

Figure 4. Concentration-response curves of compound $2 \mathrm{f}$ in endothelium-intact (E+) and endothelium-denuded (E-) aortic rings pre-contracted with Phe $1 \mu \mathrm{M}$. (a) Cumulative concentrations ( $30 \mathrm{nM}, 100 \mathrm{nM}, 300 \mathrm{nM}, 1 \mu \mathrm{M}, 3 \mu \mathrm{M}, 10 \mu \mathrm{M}$ and $30 \mu \mathrm{M}$ ) were added to the Phe contraction plateau. (b) Representative record of vasorelaxation induced by the cumulative addition $(1 \mu \mathrm{M}, 3 \mu \mathrm{M}, 10 \mu \mathrm{M}$ and $30 \mu \mathrm{M}$ ) of compound $\mathbf{2 f}$ in endothelium-intact $(\mathrm{E}+)$ aortic rings pre-contracted with Phe $1 \mu \mathrm{M}$. (c) Representative record of vasorelaxation induced by the cumulative addition $(1 \mu \mathrm{M}, 3 \mu \mathrm{M}, 10 \mu \mathrm{M}$ and $30 \mu \mathrm{M}$ ) of compound $\mathbf{2 f}$ in endothelium-denuded (E-) aortic rings pre-contracted with Phe $1 \mu \mathrm{M}$. All data are expressed as mean \pm standard error of the mean (SEM) $(n=4)$. ( ${ }^{* * *} P<0.0001 \mathrm{E}+\mathrm{vs}$. E-).

Based on the results of the MTT assay (Figure 5), it was observed that none of the compounds induced a significant difference in the percentage of cell viability at the lowest concentrations used (0.3-10 $\mu \mathrm{M})$. Although all six compounds (2a-2f) showed a significant difference at the highest concentration of $30 \mu \mathrm{M}$, it is important to note that the percentage of living cells in this case was above 70\%, except for compound 2b (69.05\%). According to ISO 10993: 5 (2009), samples that reduce cell viability values below $70 \%$ should be considered cytotoxic. Therefore, only compound $\mathbf{2 b}$ could be considered cytotoxic at the concentration of $30 \mu \mathrm{M}$. In addition, we highlight that these compounds in general had $\mathrm{IC}_{50}$ values below $30 \mu \mathrm{M}$.

The main findings show that compounds $\mathbf{2 a}-\mathbf{2} \mathbf{f}$ were able to relax the aorta. Furthermore, the results indicate an effect directly related to the presence of the endothelium for the $2 \mathrm{f}$ analogue. Therefore, it is possible that vasorelaxation is dependent on the modulation of some signalling pathway triggered by endothelium-derived factors (EDFs) [24]. It is noteworthy that nitric oxide (NO) is one of the principle vasodilators related to tone control in most vessels, so our results with the $\mathbf{2 f}$ derivative suggest the possibility of the involvement of NO in the observed vasorelaxation [25]. However, other physiological mechanisms that play a role in the activity of the vascular smooth muscle contractile machinery cannot be disregarded [26,27]. Consequently, some other protocols must be tested to study the influence of other pathways on the observed response. 


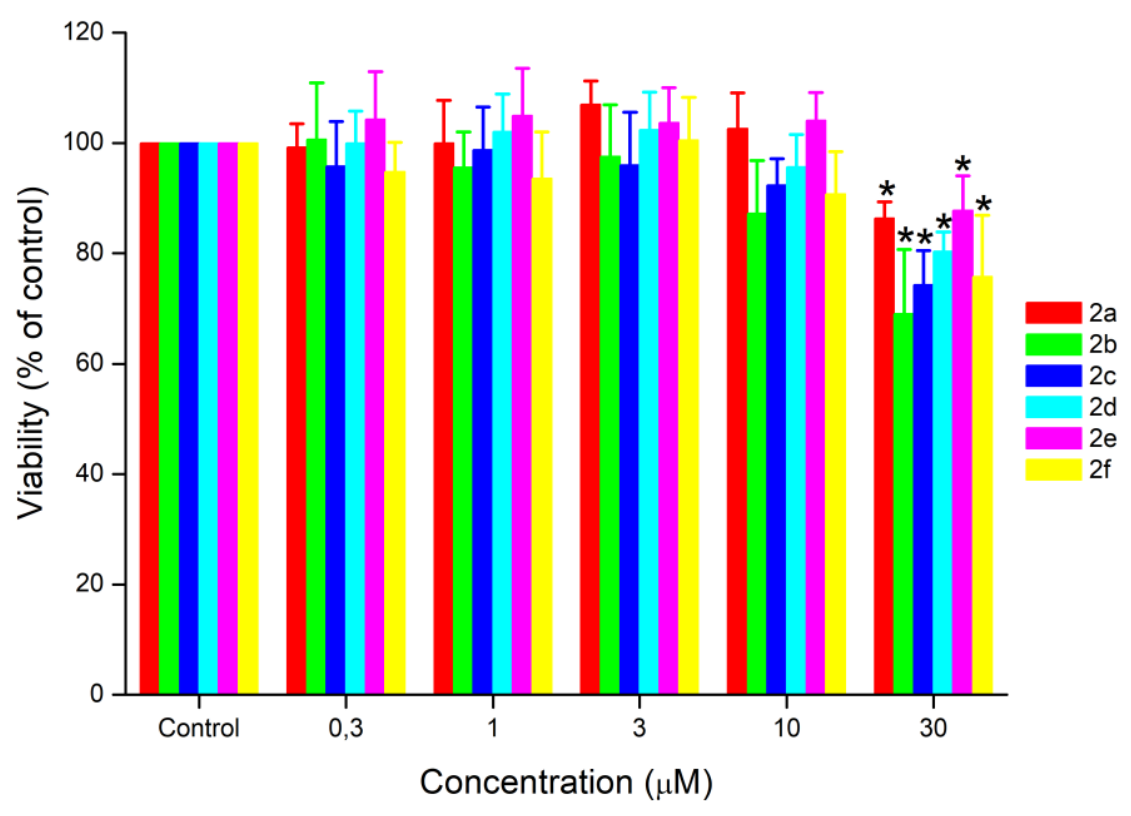

Figure 5. Cell viability assessed by the MTT method on the VERO cell line after $48 \mathrm{~h}$ of exposure to the compounds. The cells were exposed to different concentrations of the compounds $(0.3 \mu \mathrm{M}, 1 \mu \mathrm{M}, 3 \mu \mathrm{M}$, $10 \mu \mathrm{M}$ and $30 \mu \mathrm{M})$. All data are expressed as mean \pm standard error of the mean (SEM) $(\mathrm{n}=22-25)$. (DMSO maximum final concentration at $0.3 \%)\left({ }^{*} P<0.05\right.$, compound vs. control).

As is broadly known, endothelial dysfunction is one of the relevant features in the pathophysiology of hypertensive disorders such as hypertension [28]. Therefore, substances that directly affect endothelial functional regulation such as the quinazoline derivatives studied in the present paper may have significant potential in the treatment of circulation diseases [29].

\section{Materials and Methods}

\subsection{General Information}

The reactions were carried out in a 300-W CEM Discover focused microwave reactor (CEM Microwave Technology Ltd., Buckingham, UK). Reagents were purchased from Sigma-Aldrich Brazil (São Paulo, SP, Brazil) or donated by Nortec Química S/A (2-aminobenzophenones 1b-f) and were used without further purification. Column chromatography was performed with silica gel 60 (Merck 70-230 mesh, RJ, Brazil). Analytical thin-layer chromatography (TLC) was performed with silica gel plates (Merck, TLC silica gel 60 F254), and the plots were visualized using UV light or aqueous solutions of ammonium sulphate. Yields refer to chromatographically and spectroscopically homogeneous materials.

\subsection{Chemistry}

\subsubsection{General Procedure for the Preparation of $\mathbf{2 a}-\mathbf{f}$}

\section{Conventional}

A mixture of 2-aminobenzophenone $1 \mathbf{a}-\mathbf{f} \mathbf{f}(1 \mathrm{mmol})$ and urea $(15 \mathrm{mmol})$ in glacial acetic acid $(10 \mathrm{~mL})$ was stirred at $140^{\circ} \mathrm{C}$ and the progress of the reaction was monitored by TLC. After completion of the reaction, the reaction mixture was filtered, and the precipitate was washed with water. The physical and spectroscopic data were previously reported in the literature for $\mathbf{2 a}, \mathbf{2 e}$ and $\mathbf{2 f}$ [30]; $\mathbf{2} \mathbf{b}$ and $\mathbf{2} \mathbf{d}$ [31]; 2c [18]. 
Microwave Irradiation

A mixture of 2-aminobenzophenone 1a-f $(1 \mathrm{mmol})$ and urea $(15 \mathrm{mmol})$ in glacial acetic acid $(10 \mathrm{~mL})$ was irradiated in a sealed tube at $140{ }^{\circ} \mathrm{C}(200 \mathrm{w})$ for $30-45 \mathrm{~min}$ in a CEM Discover microwave reactor. The reaction mixture was filtered, and the precipitate was washed with water.

\subsection{Sample Preparation}

All compounds were dissolved with DMSO 100\% to obtain a stock solution of $10 \mathrm{mM}$. In all experiments, the stock solution was employed to obtain a final concentration diluted in Krebs Henseleit solution (vascular reactivity assay) and DMEM supplemented with 10\% FBS (cytotoxicity assay).

\subsection{Animals}

Male Wistar normotensive rats (Rattus norvegicus) weighing between 200 and 300 grams were supplied by the Central Animal Facility of Fluminense Federal University (NAL-UFF) (Rio de Janeiro, Brazil). The animals were kept in standard environmental conditions of temperature $\left(22 \pm 1^{\circ} \mathrm{C}\right)$ and $12 \mathrm{~h}$ light/dark cycle, with free access to food (Purina, Brazil) and water. All experiments were conducted in accordance to the guidelines established by National Council for Animal Experimentation Control (CONCEA, Brazil). This study was approved by the Ethics Committee in the Use of Animals of the Fluminense Federal University (CEUA-UFF), certificate under protocol number: 795/2017.

\subsection{Compounds and Solution}

L-phenylephrine hydrochloride (Phe), acetylcholine chloride (Ach) and dimethyl sulfoxide (DMSO) were purchased from Sigma-Aldrich (São Paulo, Brazil). Reagents employed in the preparation of Krebs Henseleit solution were all obtained from Merck (Rio de Janeiro, Brazil).

\subsection{Vascular Reactivity}

Animals were anesthetized by isoflurane $(1 \% \mathrm{mg} / \mathrm{kg})$ inhalation and, after the loss of motor control, rats were euthanized by cervical dislocation. Subsequently, the thoracic aorta was dissected and cleaned of connective tissue to obtain rings $4 \mathrm{~mm}$ in length that were suspended in a $15 \mathrm{~mL}$ organ bath (Panlab four chamber organ bath, AD-Instruments, Sydney, Australia). Tissues were kept in Krebs Henseleit solution at $37^{\circ} \mathrm{C}$ with the following composition (mM): $\mathrm{NaCl} 120 ; \mathrm{KCl} 5.0 ; \mathrm{MgCl}_{2}$ 1.1; $\mathrm{CaCl}_{2}$ 2.5; $\mathrm{NaH}_{2} \mathrm{PO}_{4}$ 1.2; N-[2-hydroxyethyl] piperazine-N'-[2-ethane-sulfonic acid] (HEPES) 10; $\mathrm{NaHCO}_{3} 15$; and glucose 11 , bubbled constantly with a gas mixture of $95 \% \mathrm{O}_{2}$ and $5 \% \mathrm{CO}_{2}(\mathrm{pH} 7.4)$. Each arterial segment was suspended between two steel hooks connected to an isometric transducer to measure tension through a data acquisition system (PowerLab 8 and LabChart Pro, AD-Instruments, Australia). After a stabilization period of $60 \mathrm{~min}$ at a rest tension of $1.0 \mathrm{~g}$ with periodic changes of solution (every $15 \mathrm{~min}$ ), a stable contraction was achieved with $1 \mu \mathrm{M}$ Phe. Functional endothelial integrity was assessed by the ability of $10 \mu \mathrm{M}$ ACh to induce $\geq 70 \%$ relaxation in vessels pre-contracted with $1 \mu \mathrm{M}$ Phe.

\subsection{Cytotoxicity}

A 3-[4,5-dimehyl-2-thiazolyl]-2,5-diphenyl-2H-tetrazoliumbromide (MTT) assay was employed to assess the general cytotoxicity for 4-phenylquinazolin-2 $(1 \mathrm{H})$-one derivatives. VERO cells (African Green monkey (Cercopithecus aethiops) kidney cell line) were used and obtained from the Rio de Janeiro Cell Bank (PABCAM, Federal University, Rio de Janeiro, Brazil) and grown in Roswell Park Memorial Institute medium (Sigma-Aldrich, St. Louis, MO, USA) supplemented with 10\% heat-inactivated fetal bovine serum (FBS; Gibco BRL, Gaithersburg, MD, USA), without antibiotics. Cells were plated in plastic Petri dishes and incubated at $37{ }^{\circ} \mathrm{C}$ under a $95 \% \mathrm{O}_{2} / 5 \% \mathrm{CO}_{2}$ atmosphere. Cell culture was maintained up to 15 days until cells reached $90 \%$ confluence. 
The MTT cell viability assay investigates the number of viable cells by measuring the mitochondrial-dependent reduction of water-soluble tetrazolium into an insoluble formazan product. The absorbance obtained is directly proportional to the activity of functional mitochondria and represents the number of viable cells. Briefly, VERO cells were seeded at a density of $1 \times 10^{4}$ cells per well in 96-well plates containing $200 \mu \mathrm{L}$ of DMEM culture medium supplemented with $10 \%$ FBS and incubated at $37^{\circ} \mathrm{C}$ and $5 \% \mathrm{CO}_{2}$ atmosphere. After the first $24 \mathrm{~h}$, either vehicle only (control) or compounds $(0.3,1,3,10$ and $30 \mu \mathrm{M})$ were added to the culture medium and VERO cells were incubated for an additional $48 \mathrm{~h}$. At the end of the treatment period, the medium was replaced with complete fresh medium containing $5 \mathrm{mg} / \mathrm{mL}$ tetrazolium dye (MTT) and incubated for $3 \mathrm{~h}$; then, the medium was removed and $100 \mu \mathrm{L}$ of DMSO was added. Absorbance was measured with a plate reader (SpectraMax 190, CA, USA) at a wavelength of $550 \mathrm{~nm}$ and expressed as a percentage of the control (vehicle).

\subsection{Expression of Data and Statistical Analysis}

Values are expressed as mean \pm standard error of mean (SEM). A $P$-value less than 0.05 was termed statistically significant. The $\mathrm{IC}_{50}$ values (defined as the concentration of the test compound that reduced $50 \%$ of the maximal contraction) were obtained by actual concentration-response curve fitting using GraphPad Prism 6.0 software (GraphPad Software, San Diego, CA). Statistical significance was determined using Bonferroni's multiple comparison for vascular reactivity experiments and using Turkey's multiple comparison for cytotoxicity evaluation following two-way analysis of variance (ANOVA).

\section{Conclusions}

All tested compounds were obtained through simple synthetic reactions using simple methodologies. The reaction methodology using microwave irradiation provided better yields and lower reactional times when compared with the traditional methodology. In vitro screening for a relaxant effect on aorta rings isolated from rats showed that compounds $\mathbf{2 a}-\mathbf{f}$ exhibited significant concentration-dependent effects that were dependent on the presence of an intact endothelium, suggesting a mechanism of action mediated by endothelium-derived factors (EDFs). Additionally, only one of the active compounds exhibited significant cytotoxicity at the highest concentration employed, suggesting low toxicity. Nevertheless, further toxicity investigations are required to ensure these findings. In conclusion, this series of molecules displayed the potential to serve as templates for the development of new drugs for diseases involving vascular smooth muscle, especially in disorders in which endothelial dysfunction is a relevant pathophysiological feature.

Author Contributions: R.T.: experimental design, in vitro experiments, data analysis, interpretation and writing original draft preparation. T.M.: cytotoxicity evaluation. G.A.: compound synthesis. B.C.: compound synthesis, data analysis and data interpretation. C.P.: cytotoxicity evaluation, data interpretation, data analysis and supervision. W.C.S.: experimental design, data analysis, data interpretation, supervision, manuscript drafting and editing. G.R.: compound synthesis, data analysis, data interpretation and manuscript writing. All authors have read and agreed to the published version of the manuscript.

Funding: FAPERJ (Brazil), CAPES (Brazil), Fundación Carolina (España), Instituto Nacional de Ciência e Tecnologia (INCT REDOXOMA, CNPq) and Instituto Federal do Rio de Janeiro.

Acknowledgments: We would like to thank Faculdade de Farmácia of Universidade Federal Fluminense, Núcleo de Ciências Biomédicas Aplicadas and Núcleo de Ciências Químicas of Instituto Federal do Rio de Janeiro on research facility support. We would like to acknowledge Nortec Química S/A for donation of benzophenones 1b-f.

Conflicts of Interest: The authors declare no conflict of interest. 


\section{References}

1. McGrath, N.A.; Brichacek, M.; Njardarson, J.T. A graphical journey of innovative organic architectures that have improved our lives. J. Chem. Educ. 2010, 87, 1348-1349. [CrossRef]

2. Khan, I.; Ibrar, A.; Abbas, N.; Saeed, A. Recent advances in the structural library of functionalized quinazoline and quinazolinone scaffolds: Synthetic approaches and multifarious applications. Eur. J. Med. Chem. 2014, 76, 193-244. [CrossRef] [PubMed]

3. Khan, I.; Zaib, S.; Batool, S.; Abbas, N.; Ashraf, Z.; Igbal, J.; Saeed, A. Quinazolines and quinazolinones as ubiquitous structural fragments in medicinal chemistry: An update on the development of synthetic methods and pharmacological diversification. Bioorg. Med. Chem. 2016, 24, 2361-2381. [CrossRef] [PubMed]

4. Hameed, A.; Al-Rashida, M.; Uroos, M.; Ali, S.A.; Arshia Ishtiaq, M.; Khan, K.M. Quinazoline and quinazolinone as important medicinal scaffolds: A comparative patent review (2011-2016). Exp. Opin. Ther. Pat. 2018, 28, 281-297. [CrossRef] [PubMed]

5. Rashmi, A.; Ashish, K.; Gill, N.S.; Rana, A.C. Quinazolinone: An Overview. Int. Res. J. Pharm. 2011, 2, $22-28$.

6. Pathak, S.; Malhotra, V.; Nath, R.; Shanker, K. Synthesis and Antihypertensive Activity of Novel Quinazolin-4(3H)-one Derivatives. Cent. Nerv. Syst. Agents Med. Chem. 2014, 14, 34-38. [CrossRef] [PubMed]

7. Alagarsamy, V.; Chitra, K.; Saravanan, G.; Solomon, V.R.; Sulthana, M.T.; Narendhar, B. An overview of quinazolines: Pharmacological significance and recent developments. Eur. J. Med. Chem. 2018, 151, 628-685. [CrossRef]

8. Jain, K.S.; Bariwal, J.B.; Kathiravan, M.K.; Phoujdar, M.S.; Sahne, R.S.; Chauhan, B.S.; Shah, A.K.; Yadav, M.R. Recent advances in selective $\alpha 1$-adrenoreceptor antagonists as antihypertensive agents. Bioorg. Med. Chem. 2008, 16, 4759-4800. [CrossRef]

9. Seo, H.N.; Choi, J.Y.; Choe, Y.J.; Kim, Y.; Rhim, H.; Lee, S.H.; Kim, J.; Joo, D.J.; Lee, J.Y. Discovery of potent T-type calcium channel blocker. Bioorg. Med. Chem. Lett. 2007, 17, 5740-5743. [CrossRef]

10. Venkatesh, R.; Kasaboina, S.; Gaikwad, H.; Janardhan, S.; Bantu, R.; Nagarapu, L.; Sastry, G.N.; Banerjee, S.K. Design and synthesis of 3- ( 3- (( 9 H -carbazol-4-yl) oxy ) -2- hydroxypropyl ) -2-phenylquinazolin-4 ( $3 \mathrm{H}$ ) -one derivatives to induce ACE inhibitory activity. Eur. J. Med. Chem. 2015, 96, 22-29. [CrossRef]

11. Paracha, T.U.; Pobsuk, N.; Salaloy, N.; Suphakun, P.; Pekthong, D.; Hannongbua, S.; Choowongkomon, K.; Khorana, N.; Temkitthawon, P.; Ingkaninan, K.; et al. Elucidation of vasodilation response and structure activity relationships of N2,N4 -disubstituted quinazoline 2,4-diamines in a rat pulmonary artery model. Molecules 2019, 24, 281. [CrossRef] [PubMed]

12. Gatadi, S.; Lakshmi, T.V.; Nanduri, S. 4 (3 H) -Quinazolinone derivatives: Promising antibacterial drug leads. Eur. J. Med. Chem. 2019, 170, 157-172. [CrossRef] [PubMed]

13. El-Messery, S.M.; Hassan, G.S.; Nagi, M.N.; Habib, E.S.E.; Al-Rashood, S.T.; El-Subbagh, H.I. Synthesis, biological evaluation and molecular modeling study of some new methoxylated 2-benzylthio-quinazoline4(3H)-ones as nonclassical antifolates. Bioorg. Med. Chem. Lett. 2016, 26, 4815-4823. [CrossRef] [PubMed]

14. Abuelizz, H.A.; Marzouk, M.; Ghabbour, H.; Al-Salahi, R. Synthesis and anticancer activity of new quinazoline derivatives. Saudi Pharm. J. 2017, 25, 1047-1054. [CrossRef] [PubMed]

15. Saravanan, G.; Panneerselvam, T.; Alagarsamy, V.; Kunjiappan, S.; Parasuraman, P.; Murugan, I.; Kumar, D.P. Design, graph theoretical analysis, density functionality theories, Insilico modeling, synthesis, characterization and biological activities of novel thiazole fused quinazolinone derivatives. Drug Dev. Res. 2018, 79, 260-274. [CrossRef]

16. Widler, L.; Altmann, E.; Beerli, R.; Breitenstein, W.; Bouhelal, R.; Buhl, T.; Gamse, R.; Gerspacher, M.; Halleux, C.; John, M.R.; et al. 1-Alkyl-4-phenyl-6-alkoxy-1H-quinazolin-2-ones: A novel series of potent calcium-sensing receptor antagonists. J. Med. Chem. 2010, 53, 2250-2263. [CrossRef]

17. Sandoz, A.; Gamboni, G.; Schmid, M.W.; Sutter, B.A. Preparation of Quinazolin-2(1H)-Ones. U.S. Patent 4236006, 25 November 1980.

18. Barthel, A.; Trieschmann, L.; Ströhl, D.; Kluge, R.; Böhm, G.; Csuk, R. Synthesis of dimeric quinazolin-2-one, 1,4-benzodiazepin-2-one, and isoalloxazine compounds as inhibitors of amyloid peptides association. Arch. Pharm. Chem. Life Sci. 2009, 342, 445-482. [CrossRef]

19. Barrow, J.C.; Rittle, K.E.; Reger, T.S.; Yang, Z.Q.; Bondiskey, P.; McGaughey, G.B.; Bock, M.G.; Hartman, G.D.; Tang, C.; Ballard, J.; et al. Discovery of 4,4-disubstituted quinazolin-2-ones as T-type calcium channel antagonists. ACS Med. Chem. Lett. 2010, 1, 75-79. [CrossRef] 
20. Crespo, A.; Coelho, A.; Diz, P.M.; Fernández, F.; De Armas, H.N.; Sotelo, E. Convergent assembly of structurally diverse quinazolines. Org. Biomol. Chem. 2011, 9, 351-357. [CrossRef]

21. Pham, T.T.; Walden, M.; Butler, C.; Diaz-Gonzalez, R.; Pérez-Moreno, G.; Ceballos-Pérez, G.; Gomez-Pérez, V.; García-Hernández, R.; Zecca, H.; Krakoff, E.; et al. Novel 1,2-dihydroquinazolin-2-ones: Design, synthesis, and biological evaluation against Trypanosoma brucei. Bioorg. Med. Chem. Lett. 2017, 27, 3629-3635. [CrossRef]

22. Westman, J.; Lidstrom, P.; Tierney, J.; Whatey, B. Microwave assisted organic synthesis-A review. Tetrahedron 2001, 57, 9225-9283.

23. Kappe, C.O. My twenty years in microwave chemistry: From kitchen ovens to microwaves that aren't microwaves. Chem. Rec. 2018, 18, 1-26. [CrossRef] [PubMed]

24. Nava, E.; Llorens, S. The local regulation of vascular function: From an inside-outside to an outside-inside model. Front. Physiol. 2019, 10, 1-15. [CrossRef] [PubMed]

25. Fleming, I.; Busse, R. NO: The primary EDRF. J. Mol. Cell Cardiol. 1999, 31, 5-14. [CrossRef] [PubMed]

26. Quast, U.; Guillon, J.M.; Cavero, I. Cellular pharmacology of potassium channel openers in vascular smooth muscle. Cardiovasc. Res. 1994, 28, 805-810. [CrossRef] [PubMed]

27. Walsh, M.P.; Kargacin, G.J.; Kendrick-Jones, J.; Lincoln, T.M. Intracellular mechanisms involved in the regulation of vascular smooth muscle tone. Can. J. Physiol. Pharmacol. 1995, 73, 565-573. [CrossRef]

28. Virdis, A.; Taddei, S. Endothelial Dysfunction in Resistance Arteries of Hypertensive Humans: Old and New Conspirators. J. Cardiovasc. Pharmacol. 2016, 67, 451-457. [CrossRef]

29. Vanhoutte, P.M.; Shimokawa, H.; Feletou, M.; Tang, E.H.C. Endothelial dysfunction and vascular disease-A 30th anniversary update. Acta Physiol. 2017, 219, 22-96. [CrossRef]

30. Voronina, T.A.; Gordiichuk, G.N.; Andronati, S.A.; Garibova, T.L.; Zhilina, Z.I. Synthesis and pharmacological properties of some 4-phenyl-quinazoline-2-ones. Pharm. Chem. J. 1981, 15, 495-497. [CrossRef]

31. Altmann, E.; Beerli, R.; Gerspacher, M.; Renaud, J.; Weiler, S.; Widler, L. Aryl-quinazoline/aryl-2amino-phenyl methanone derivatives. U.S. Patent WO 2004/056365A2, 08 July 2004.

Sample Availability: Samples of the compounds 4-phenylquinazolin-2(1H)-one derivates are available from Gabriel Resende.

(C) 2020 by the authors. Licensee MDPI, Basel, Switzerland. This article is an open access article distributed under the terms and conditions of the Creative Commons Attribution (CC BY) license (http://creativecommons.org/licenses/by/4.0/). 